Hikmah: Journal of Islamic Studies, 16 (1), 2020, 38-56

http://journal.uinjkt.ac.id/index.php/HIKMAH

DOI: 10.47466/hikmah.v16i1.166 | P-ISSN. 2088-2629, E-ISSN. 2581-0146

\title{
TRANSFORMISME PENDIDIKAN DI NEGARA MAJU: INISIATIF FILOSOFIS PENGEMBANGAN MUTU PENDIDIKAN DI INDONESIA
}

\author{
Zaenal Arifin \\ Sekolah Tinggi Ilmu Tarbiyah Sunan Giri Trenggalek \\ arzafin@gmail.com
}

\begin{abstract}
Finland has been acknowledged as having the best education system in the world. Many countries, such as Australia, Japan and Singapore, adopted Finland education system. Those countries have reformed and transformed their education system, and now, those countries are listed in the best management and quality education countries. The integration among curricula, market and philosophical values of nation founding fathers as world view has resulted transformation of education. Programme for Internasional Student Assessment (PISA) 2019 assessed the quality of education in term of reading, math and science and made Indonesia ranked on the 72nd out of 77 countries. In other word, Indonesia is the 6th ranking from below. At the same time, Singapura took the runner up position. Indonesia has left behind from other countries, including Malaysia and Brunei. It is imperative for Indonesia to learn more to those countries which succeeded in designing the system of education. By doing this, Indonesia will be equal to neighboring countries.
\end{abstract}

Keywords: Education; Transformation; Quality of education

\begin{abstract}
Abstrak
Finlandia diakui memiliki sistem pendidikan terbaik di dunia. Banyak negara di dunia belajar dari kesuksesan Finlandia, seperti Australia, jepang dan singapura. Ketiga negara ini, telah melakukan reformasi bahkan transformasi pendidikan untuk memperbaiki sistem pendidikannya sehingga sekarang mampu menempatkan diri dalam jajaran negara-negara terbaik dalam manajemen mutu pendidikan. Sinergi aspek kebijakan, kurikulum dan pasar serta nilai-nilai filosofis sebagai pandangan hidup yang telah dilahirkan para pendiri bangsa telah melahirkan transformisme pendidikan. Pada tahun 2019, Programme for Internasional Student Assessment (PISA) yang merupakan lembaga survei kualitas pendidikan di dunia dari aspek kemampuan membaca, matematika, dan sains telah menempatkan Indonesia pada urutan 72 dari 77 negara. Jadi, Indonesia berada pada peringkat keenam dari bawah sedangkan Singapura berada pada posisi kedua terbaik dan juga jauh tertinggal di belakang negara-negara tetangga lainnya, seperti seperti Malaysia dan Bruai Darusaalam. Indonesia harus banyak belajar dari negera-negara yang telah sukses mendesain sistem pendidikan yang baik sehingga kualitas, mutu pendidikan dapat disejajarkan dengan negara-nega lainnya.
\end{abstract}

Kata Kunci: Pendidikan; Transformasi; Mutu pendidikan 


\section{PENDAHULUAN}

Suatu negara dianggap maju tidak berarti pula dinggap kaya. Negara maju merupakan status suatu negara yang didasarkan pada kualitas hidup masyarakat bukan pada seberapa besar kekayaan negara yang dimiliki namun secara umum negara yang memiliki kualitas hidup baik, biasanya pertumbuhan ekonominya pun tumbuh dengan baik. Kualitas hidup masyarakat di negara maju banyak dipengaruhi oleh penguasaan ilmu pengetahuan dan teknologi. Oleh karena itu, pengembangan pendidikan di negara maju diorientasikan secara optimal pada pemberdayaan peningkatan sumberdaya manusia (SDM) melalui penguasaan ilmu pengetahuan dan teknologi dalam mengahadapi era globalisasi.

Pendidikan di semua belahan bumi pada gilirannya didorong dan dipaksa untuk bertransformasi menghadapi era globalisasi. Pendidikan yang menghasilkan sumber daya manusia (SDM) unggul yang akan diterima pada situasi ini sehingga negara, seperti Indonesia yang masih menempati peringkat pendidikan rendah memerlukan berbagai upaya untuk mengembangkan mutu pendidikan. SDM yang meliputi pengetahuan, keterampilan dan keahlian (skill) dalam bidang sains dan teknologi menjadi "nyawa" negara di era globalisasi, siapa yang bertahan hidup atau mati ditentukan dari SDM yang dimiliki.

Transformasi pendidikan yang telah dilakukan di beberapa negara maju, seperti Singapura, Kanada, Inggris, Australia, maupun Jepang meliputi beberapa aspek, yaitu kebijakan, kualitas guru dan kualitas pembelajaran. Transformasi pendidikan yang dilakukan telah mampu mengembangkan mutu pendidikan sehingga menghasilkan SDM yang mampu menjawab tantangan ekonomi global. Keberhasilan ini tidak terlepas dari semboyan filosofis yang mendasari reformasi dan transformasi pendidikan di beberapa negara tersebut, seperti "to bulid nation build education" di Jepang, "no child left behind" di Amerika, dan "pendidikan berdaulat dan berdikari" di Inggris. Berbekal semangat transformasi dalam mewujudkan filosofi pendidikan dalam menghadapi perubahan cepat dunia ini mengukuhkan diri mereka sebagai penyelenggara pendidikan terbaik di dunia.

Gambaran bagaimana pengembangan mutu pendidikan negara maju melalui upaya transformasi yang telah dilakukan menjadi urgen untuk dibahas sebagai bahan rujukan yang mungkin cocok bagi pengembangan mutu pendidikan Indonesia, termasuk di dalamnya pendidikan Islam. Transformasi dalam bingkai pengembangan mutu pendidikan di era globalisasi bukan lagi suatu pilihan, tetapi suatu jalan yang Indonesia harus tempuh agar survive dan mampu memenuhi kebutuhan masyarakat dunia akan pendidikan. Oleh karena itu, di sinilah pentingnya mempelajari bagaimana mengananlisis bagaimana proses pengembangan mutu pendidikan di negara maju. 


\section{METODE}

Penelitian ini merupakan studi analisis model pengembangan mutu pendidikan di tiga negara maju, yaitu Australia, Jepang, dan Singapura dilihat dari aspek kebijakan, kualitas guru, kurikulum dan kualitas pembelajaran. Melalui studi singkat ini, diharapkan menjadi wacana yang semakin memberi kesadaran akan pentingnya transformasi pendidikan maupun pendidikan Islam khususnya sehingga lahir desain pendidikan yang tepat dalam upaya meningkatkan mutu SDM sesuai dengan perkembangan dan kebutuhan peserta didik dalam rangka mencapai tujuan pendidikan nasional, yaitu membentuk manusia Indonesia seutuhnya yang mampu bersaing dikancah internasional.

\section{HASIL DAN PEMBAHASAN}

Berbicara mengenai negara maju tidak berbicara tentang negara kaya. Negara maju merupakan status suatu negara yang didasarkan pada kualitas hidup masyarakat bukan pada seberapa besar kekayaan negara yang dimiliki. Akan tetapi, secara umum negara yang memiliki kualitas hidup baik biasanya pertumbuhan ekonomi juga tumbuh dengan baik. Awal abad XXI ini muncul beberapa negara yang dianggap dan diakui dunia sebagai negara yang maju. Kualitas hidup dan tingkat pertumbuhan ekonomi yang baik seiring dengan berbagai upaya negara tersebut menata dan mereformasi segala aspek kehidupan berbangsa dan bernegara, khususnya bidang pendidikan.

Di tahun 2016 ini ada beberapa negara yang tetap bertahan dalam peringkat negara yang menunjukkan kualitas mutu pendidikan yang tinggi sebagaimana tahun sebelumnya. Namun ada pula yang melakukan transformasi yang luar biasa sehingga menunjukkan perubahan perubahan besar yang membuat mereka menjadi rujukan pengembangan mutu pendidikan dari negara-negara lain. Beberapa negara maju yang dapat dijadikan rujuka, antara lain Australia, Jepang, dan Singapura.

\section{Australia}

Reformasi pendidikan yang terjadi di Australia terkait erat dengan resonansi reformasi yang terjadi di beberapa negara, seperti Amerika, Inggris dan New Zealand dan beberapa negara lain. Namun secara internal, terdapat beberapa faktor atau aspek yang berpengaruh mendorong terjadinya reformasi bidang pendidikan di Australia. Menurut Barcan sebagaimana dijelaskan Esha, bahwa setidaknya ada empat faktor yang mendorong reformasi pendidikan di Australia, yaitu (1) terjadinya krisis dari negara kesejahteraan dan munculnya ekonomi neoliberalisme yang lebih menekankan pada nilai-nilai kompetisi, pasar bebas, dan meminimalkan intervensi negara; (2) adanya kecenderungan pemerintah untuk melakukan efisiensi dengan mengurangi biaya belanja negara terhadap birokrasi pendidikan dan pelayanan pendidikan; (3) kecenderungan masyarakat Australia untuk 
mencari pendidikan yang kurikulumya mengorientasikan pendidikannya pada kebutuhan pasar atau pendidikan yang bersifat vokasional. Di samping itu, masyarakat Australia mulai menuntut kualitas pendidikan yang tinggi; dan (4) adanya ketidakpuasan yang dirasakan oleh para orang tua di Australia terhadap pelayanan yang diberikan oleh sekolah-sekolah pemerintah. $^{1}$

Kondisi di atas medorong Australia melakukan reformasi yang lekat dengan paradigma yang dikenal dengan istilah New Public Management (NPM). Perubahan dari administrasi publik yang kaku, hierarkis, dan birokratis menuju bentuk manajemen publik yang fleksibel dan berbasis pasar. Implementasi NPM ini nampak pada beberapa negara bagian Austalia, seperti New South Wales (NSW), Australia Barat, Australia Selatan, maupun wilayah Utara yang termanifestasikan dalam beberapa kebijakan pendidikan.

NSW melakukan kebijakan pergeseran administrasi dari pemerintah pusat kepada sekolah masing-masing dengan mengenalkan atau membentuk komite sekolah (school council) dan perampingan atau restrukturisasi. Komite sekolah, anggotanya terdiri dari para orang tua murid dan tokoh masyarakat yang mempunyai kewenangan untuk mengukur "biaya belanja sekolah". Sedangkan di wilayah Barat tidak membentuk komite sekolah namun mengenalkan Kelompok Pembuat Kebijakan Sekolah (A School Decision Making Groups) dan menerapkan kurikulun satuan dan perbaikan kinerja dan gaji guru. Di bagian Selatan dan juga Utara melakukan banyak perampingan staf administrasi dengan jalan mentransfer tugas-tugas personil ke sekolah-sekolah, membentuk komite sekolah, perbaikan kurikulum dan desentralisasi manajerial. $^{2}$

Di bidang kompetensi pendidik (guru), contohnya Dapartment of Education and Training, Government of West Australia (2008) menetapkan kualifikasi akademik minimal diploma diploma mengajar di tingkat sekolah dasar dan Bachelor Degree untuk sekolah menengah, khususnya untuk public school. Sedangkan untuk sekolah swasta (private school) bebas mempekerjakan guru-guru terlepas dari tingkat kualifikasinuya, walaupun dalam praktiknya sebagian besar guru swasta di Australia Barat memiliki kualifikasi sarjana. Kompetensi guru di Australia Barat tergambar dari Competency Framework for Teachers seperti gambar berikut: ${ }^{3}$

\footnotetext{
${ }^{1}$ Muhammad In'am Esha, Institutional Transformation: Reformasi Dan Modernisasi Pendidikan Tinggi Islam (Malang: Uin-Malang Press, Cet. 1, 2009), H. 45-47.

${ }^{2}$ Muhammad In'am Esha, Institutional Transformation, H. 47-49.

${ }^{3}$ Mawardi, Standar Kualifikasi Dan Kompetensi Guru Profesional Di Indonesia Dan Australia Barat, EJournal Scholaria, Vol. 4, No. 2, Juli 2014, H. 3-4. Dalam Http://Ris. Uksw.Edu/ Jurnal/Read/Kode/J00848
} 


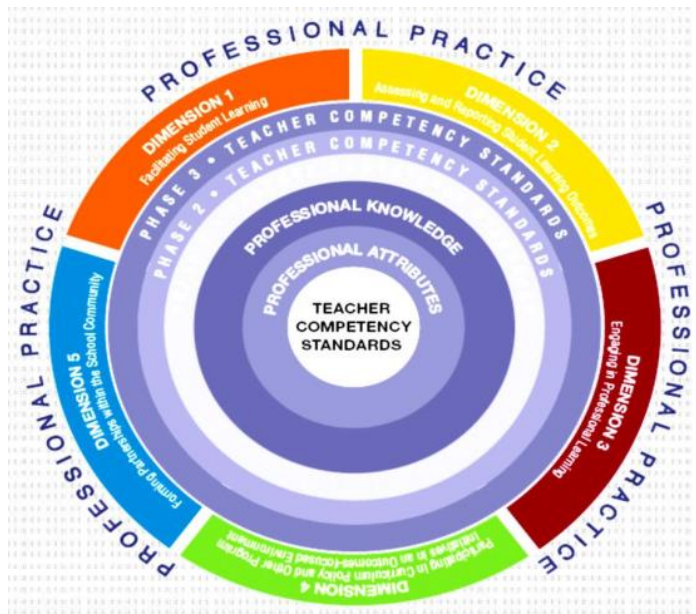

Gambar 1. Competency Framework for Teachers in Australia

Dari gambar di atas, terdapat tiga kompetensi guru, yaitu professional attributes (kompetensi yang melekat pada diri guru profesional), professional knowledge (kompetensi pengetahuan profesional), dan professional practice (kompetensi praktik profesional) Dari dua kompetensi pertama terdapat 5 dimensi yang wajib dilakukan guru selama proses pembelajaran, yaitu (1) facilitating student learning; (2) assesing and reporting student learning; (3) engaging profesional learning; (4) participating incurriculum policy and other program initiatives in an outcames-focused invironment; (5) Forming partnership within the school community.

Pengembangan profesionalisme di Australia diatur oleh departemen pendidikan di masing-masing Australian Capital Territory (ACT). Di Australia Barat pengembangan profesionalisme guru diselenggarakan oleh Institute for Professional Learning. Institut tersebut menerima aplikasi dan menyelenggarakan pendidikan dan latihan guru sesuai dengan jalur karier yang dipilihnya sendiri. Ada tiga jalur karier yang disediakan, yaitu: 1) guru senior (senior teacher), 2) guru kelas tingkat 3 (level 3 classroom teacher), dan 3) administrator sekolah (school administrator). Jalur karier guru senior menyiapkan guru menjadi guru saja, tanpa dituntut keaahlian khusus yang lain. Jalur guru kelas tingkat 3 menyiapkan guru kelas dan keahlian khusus tertentu (misalnya leadership). Sedangkan jalur guru administrator sekolah menyiapkan guru untuk menjadi kepala sekolah ataupun kepala/wakil kepala dinas pendidikan lokal (become a principal,deputy or head of a learning area). Pelaksanaan pendidikan dan latihan dilaksanakan dengan menggunakan modul modul diklat, baik online maupun cetak dan portofolio bagi jalur guru kelas Tingkat 3, kemudian diakhiri dengan assessment dan sertifikasi bagi yang lulus. Bagi guru negeri diberi biaya diklat sebesar $\$ 1.600$ per tahun. Ada tambahan penghasilan stelah 
memperoleh sertifat sesuai dengan jalur masing-masing. misalnya, untuk guru senior mendapat tambahan penghasilan $\$ 91.647$ setiap bulannya. ${ }^{4}$

Dalam bidang peningkatan kualitas pengajaran, Australia membedakan tujuan pendidikan sesuai dengan level atau jenjang yang telah ditetapkan undang-undang. Pada level sekolah, pendidikan diorientasikan pada pengembangan potensi siswa sedangkan pada level perguruan tingi lebih diarahkan pada pencapaian kebutuhan atau kepentingan ekonomi atau masyarakat secara umum. Di Australia, ada lima strata sekolah, yaitu Kindergarten (taman kanak-kanak) Primary School (Sekolah Dasar) sampai kelas kelas 6 atau 7, Secondary or High School (Sekolah Menengah) kelas 7 atau 8 sampai kelas 10, Vocational Education and Training (Pendidikan Kejuruan dan Pelatihan) dan senior high school/senior secondary school/college (sekolah menengah atas) kelas 11 sampai kelas 12, dan University (pendidikan tinggi). ${ }^{5}$

Pusat Pengembangan Kurikulum (Curriculum Development Centre/CDC) dibentuk oleh pemerintah Commonwealth dalam tahun 1975 untuk membantu mengkoordinasi dan mendiseminasikannya, serta menyiapkan materi kurikulum. Buku-buku pelajaran dan ujian disiapkan oleh berbagai badan termasuk seksi kurikulum, departemen pendidikan, Dewan Penelitian Pendidikan Australia (ACER), CDC, penerbit buku-buku akademik yang komersial, dan asosiasi guru-guru bidang studi. Sedangkan tanggung jawab tentang metodologi pengajaran pada prinsipnya terletak pada masing-masing guru dan sekolah. Pada umumnya format pengajaran pada pendidikan dasar dan menengah ialah seorang guru memegang satu kelas atau per bidang mata pelajaran. ${ }^{6}$

Curriculum Framework di Australia disusun dalam rangka menyongsong datangnya Abad XXI, dengan semboyan "Educating our Children to succeed in the 21th Century". Prof. Lesley Parker, Chair of the Curriculum Council, menyatakan rasa bangganya, karena "The Curriculum Framework was developed through a unique cosultative process that involved almost 10.000 teachers, parents, academics, curriculum officers, students and other members of the community". Dengan kata lain, pengembangan kurikulum di Australia telah melibatkan semua stakeholder pendidikan. ${ }^{7}$.

Ada beberapa hal yang menarik dalam Curriculum Framework, sebagaimana di rilis Autralian Bureu of Statistic tahun 1993. Pertama, ada 8 kondisi yang melatarbelakangi

\footnotetext{
${ }^{4}$ Mawardi, Standar Kualifikasi Dan Kompetensi Guru Profesional Di Indonesia Dan Australia Barat, EJournal Scholaria, Vol. 4, No. 2, Juli 2014, Dalam Http://Ris.Uksw.Edu/ Jurnal/Read/Kode/ J00848, H. 9-10.

${ }^{5}$ Saifullah, Konsep Pendidikan Jerman Dan Australia (Kajian Komparatif Dan Aplikatif Terhadap Mutu Pendidikan Indonesia), Jip-International Multidisciplinary Journal, Vol. Ii, No. 02, Mei 2014, H. 275-276. Http: / / Oaji.Net/Articles/2014/745-1402168513.Pdf.

${ }^{6}$ Saifullah, Konsep Pendidikan Jerman Dan Australia (Kajian Komparatif Dan Aplikatif Terhadap Mutu Pendidikan Indonesia), Jip-International Multidisciplinary Journal, H. 278.

${ }^{7}$ Saifullah, Konsep Pendidikan Jerman Dan Australia (Kajian Komparatif Dan Aplikatif Terhadap Mutu Pendidikan Indonesia), Jip-International Multidisciplinary Journal, H. 279.
} 
pengembangan kurikulum di Australia, yaitu (1) cultural diversity, (2) changes in the family structure, (3) rapid pace of technologival change, (4) global environmental issues, (5) changing nature of social conditions, (6) change in the workplace, (7) inter-dependence in the global economy, (8) uncertain standards of living.

Kedua, ada lima karakteristik nilai (values) yang akan dibangun melalui kurikulum tersebut, yaitu: (1) pursuit of knowledge and commitment to achievement of potential, (2) self acceptance and respect of self, (3) respect and concern for others and their rights, (4) social and civic responsibility, dan (5) environmental responsibility. ${ }^{8}$

"Curriculum Framework" tidak mengggunakan istilah "competency-based", namun menggunakan istilah "student outcomes statement" atau dikenal dengan "overarching statement learning outcomes”. Menurut D' Cruz J and P. Langford sebagaimana dikutip Saifullah, ada 13 (tiga belas) "student outcomes statement" yang akan dicapai melalui delapan mata pelajaran secara sinergis dengan menggunakan konsep "links across the curriculum”. D’ Cruz J dan P. Langford mengatakan:

"yaitu: 1) Students use language to understand, develop and communicate ideas and information and to interact with others; 2) Students select, integrate and apply numerical and spatial concepts and techniques; 3) Students recognize when and what information is needed, locate and obtain it form a range of sources and evaluate, use and share it with others; 4) Students select, use and adapt Technologies; 5) Students describe and reason about patterns, structures and relationship in order to understand, interpret, justify and make patterns; 6) Student visualize consequences, think laterally, recognize opportunity and potential and are prepared to test options; 7) Students understand and appreciate the physical, biological and technological world and have the knowledge and skills and values to make decision in relation to it; 8) Students understand their cultural, geographic and historical context and have the knowledge, skills and values necessary for active participation in life in Australia; 9) Students interact with other people and cultures other than their own and are equipped to contribute to the global Community; 10) Student participate in creative activity of their own and understand and engage with the artistic, cultural and intellectual work of others; 11) Students value and implement practices that promote personal growth and well being; 12) Students are self-motivated and confident in their approach to learning and are able to work individually and collaboratively; dan 13) Students recognize that everyone has the right to feel valued and be safe, and, in this regard, understand their rights and obligations and behave responsible.'

Sebelum upaya reformasi pendidikan seperti sekarang, Australia menggunakan sistem evaluasi eksternal yang ekstensif untuk menentukan kualifikasi siswa dan pemberian

\footnotetext{
${ }^{8}$ Saifullah, Konsep Pendidikan Jerman Dan Australia (Kajian Komparatif Dan Aplikatif Terhadap Mutu Pendidikan Indonesia), Jip-International Multidisciplinary Journal, H. 279.

${ }^{9}$ Saifullah, Konsep Pendidikan Jerman Dan Australia (Kajian Komparatif Dan Aplikatif Terhadap Mutu Pendidikan Indonesia), Jip-International Multidisciplinary Journal, H. 279-280
} 
sertifikat atau diploma. Namun setelah perang dunia II, semua diserahkan sekolah untuk melakukan ujian pada level masing-masing setiap tahun kecuali pada tingkat akhir pendidikan menegah disaat ujian eksternal dilaksanakan. Selama bertahun-tahun sistem pendidikan Australia menggunakan sistem evaluasi eksternal. Sesudah Perang Dunia II hampir semua ujian eksternal ini dihapuskan, dan pada pendidikan dasar dan menengah, yang paling banyak dilakukan ialah kenaikan kelas siswa atas dasar usia. Hampir pada semua sistem, sekolah punya tanggung jawab melakukan ujian untuk setiap level setiap tahun kecuali pada tingkat akhir pendidikan menengah di saat ujian eksternal dilaksanakan. Pada hampir seluruh sistem sekolah, sertifikat pertama yang diterima siswa adalah pada akhir tahun pendidikan ke-10 berdasarkan penilaian internal sekolah. Pemberian sertifikat yang lebih tinggi diberikan pada tahun pendidikan ke-12, pada umumnya berdasarkan ujian eksternal. Pada ACT dan negara bagian Queensland, ujian internal sekolah yang sudah terakreditasi adalah sebagai pengganti ujian eksternal pada tahun pendidikan ke-12. Untuk masuk ke universitas dan CAE (Center for Adult Education) pada umumnya diperlukan kualitas rerformasi tertentu pada tahun pendidikan ke-12, walaupun kebanyakan institusi memberikan kriteria tersendiri bagi orang-orang dewasa yang kebetulan tidak memenuhi persyaratan formal. Masuk ke TAFE (Technical And Further Education) International Student dimungkinkan setelah menamatkan pendidikan 10 tahun dengan hasil yang memuaskan. Masalah yang terdapat dalam sistem ujian dan kenaikan kelas antara lain adalah mendapatkan keseimbangan antara ujian internal sekolah dan kesulitan belajar mengajar yang mungkin muncul dalam kenaikan kelas otomatis berdasarkan usia. ${ }^{10}$

\section{Jepang}

Sejak berakhirnya kekuasaan Meiji (1862-1912), Jepang menunjukkan diri sebagai negara yang modern, tetapi tradisional pada saat yang sama, jauh dari kesan terisolasi, konservatif. Perubahan yang cepat ini terjadi karena Jepang menyesuaikan diri (mengadopsi) dengan sistem Barat baik politik, sosial, dan ekonomi. Jepang mengontrol perdagangan luar negeri dan sistem hukum dengan memerangi dan memenangkan dua perang (salah satunya melawan kekuatan besar Eropa, Rusia). Itu menunjukkan kemerdekaan penuh dan kesetaraan dalam urusan internasional. ${ }^{11}$

Seiring dengan pertumbuhan ekonomi, pendidikan Jepang diarahkan pada pemenuhan dan penyesuaian terhadap kebutuhan-kebutuhan nasional dalam memacu pertumbuhan ekonomi. Terlebih dengan globalisasi yang sedang melanda dunia secara global, tuntutan kompetisinya menjadi semkain tinggi. Sehingga perhatian terhadap

\footnotetext{
${ }^{10}$ Saifullah, Konsep Pendidikan Jerman Dan Australia (Kajian Komparatif Dan Aplikatif Terhadap Mutu Pendidikan Indonesia), Jip-International Multidisciplinary Journal, H. 280-281.

11 Tram Lie, Periode I, World History Ii: Japan Revolusion Essay, (Http://Modernhistorytram. Blogspot.Co.Id/2016/02/Japan-Revolution-Essay.Html). Diakses 18 Juli 2016
} 
prestasi akademik di masyarakat sangat urgen yang telah menciptakan situasi sosial yang dikenal dengan "examination hell syndrom". Anak-anak dituntut untuk mendapat nilai tinggi di sekolah yang menyebabkan lemahnya kohesi sosial dan pengabaian aspek-aspek emosional. Tercatat pada tahun 1970-an Jepang menghadapi banyak masalah, seperti meningkatnya angka bunuh diri remaja, penolakan anak datang ke sekolah, terjadinya kekerasan di sekolah dan rumah, dan sejenisnya. Inilah titik awal Jepang melakukan reformasi kebijakan dalam pendidikan. ${ }^{12}$

Berbagai persoalan pendidikan inilah, pada tahun 1970, The Central Council for Education (CCE) and the Third Educational Reform mendapat masukan perlunya mereformasi sistem pendidikan Jepang secara keseluruhan. Akhirnya, pada tahun 1971, CCE yang merupakan badan penasehat Menteri Pendidikan menyerahkan laporan tentang, "a fundamental policy for the comprehensive expansion of the education system". Laporan ini bertujuan untuk untuk merestrukturisasi semua tingkat pendidikan dari kindergarten (TK) sampai university (PT) yang disebut dengam istilah "the third major educational reform". ${ }^{13}$

Menghadapi berbagai persoalan sebagaimana di atas, pada tahun 1984, sebuah Badan penasehat di bawah yurisdiksi langsung dari Perdana Menteri, The Nasional Council on Education Reform (NCER, Rinkyosin) dibentuk. Pada bulan Agustus tahun 1987, Dewan ini mempromosikan beberapa prinsip pendidikan yang meliputi: (1) the principle of emphasizing the individuality of the students (prinsip penekanan pada individualitas siswa; (2) the move to a system of life long learning (pendidikan seumur hidup); and (3) the response to changes such as internationalization and advancements in information technology (respons terhadap perubahan internasional dan masyarakat dalam bidang teknologi informasi). ${ }^{14}$

Pada bulan Juli 1996, Dewan Pusat Pendidikan menyampaikan laporan pertama di “The Model Pendidikan Jepang dalam Perspektif Abad 21". Dalam laporan ini, Dewan melihat kecenderungan dunia akan penyebaran informasi, pengembangan lebih lanjut dari ilmu pengetahuan dan teknologi, lingkungan global dan masalah energi, juga masalah pergerakan bumi ke kondisi yang semakin menua ditambah dengan menurunnya tingkat kelahiran. Ini kenyataan yang dihadapi yang sulit untuk dihadapi. Oleh karena itu, anakanak perlu dipersiapkan untuk hidup dalam masyarakat seperti itu dengan dibekali kualitas atau kemampuan, sebagai berikut: (1) kemampuan dan kualitas diri yang mampu mengidentifikasi masalah diri mereka sendiri, belajar atas inisiatif sendiri dan berpikir untuk diri mereka sendiri, melakukan penilaian mereka sendiri dan bertindak secara

\footnotetext{
${ }^{12}$ Muhammad In'am Esha, Institutional Transformation ..., H. 50-51.

${ }^{13}$ Yasuo Saito, Education In Japan, Past And Present, H. 8. Https://Www.Nier.Go.Jp/ English/Educationjapan/Pdf/201103ejpp.Pdf.

${ }^{14}$ Yasuo Saito, Education In Japan, Past And Present, H. 9.
} 
independen, dan memecahkan masalah dengan baik; 2) tinggi rasa kemanusiaan, penekanan kemampuan untuk mengendalikan diri, kesediaan untuk bekerja sama dengan orang lain, dan hati yang memungkinkan mereka untuk peduli kepada orang lain dan menjadi sensitif terhadap sesuatu yang berharga dan mulia; dan 3) kesehatan dan kekuatan fisik memungkinkan mereka untuk menjalani hidup aktif. Dari laporan ini, Dewan menyimpulkan kemampuan dan kualitas siswa dapat di katakan dalam frase, "Ikiru Chikara" (competences for positive living or zest for living, kompetensi untuk hidup positif atau semangat untuk hidup). Untuk dapat menumbuhkan ini semua, perlu adanya kolaborasi antara sekolah, keluarga, dan masyarakat untuk mempunyai "yutori" (latitude and relaxing feeling). ${ }^{15}$

Pengembangan profesionalitas guru dilakukan setelah terjadi perubahan politik dua kali, 2009 dan 2012. CCE di bawah Democratic Party of Japan (DPJ) mencoba meningkatkan kualitas guru dengan menetapkan kualifikasi dasar pendidikan guru adalah minimal bergelar Master dan menempatkan guru sebagai "advanced specialized professionals". Ini dilakukan karena secara de facto dalam situasi yang complicated sekarang ini, lulusan "bachelor", sarjana tidak cukup. Hal ini karena perkuliahan biasanya berorientasi ke arah apa yang disebut "lecturer" (kuliah) dan juga banyaknya lisensi guru lebih banyak dari permintaan serutama ditingkat SMP dan SMA padahal yang paling berperan adalah "practice" (praktis). Oleh karena itu, kualifikasi dasar pendidikan guru dinaikkan ke tingkat master bertujuan untuk memperkaya pengalaman praktis di mana calon guru melakukan magang (several years of a trial period) yang kemudian mendapatkan lisensi pendidik. Semua tangungjawab mencetak guru dilakukan universitas dengan "open system” yang bekerjasama dengan sekolah di bawah pengawasan CCE dan pemerintah. ${ }^{16}$

Dalam bentuk kebijakan kurikulum, mulai tahun 1992 dan sejak tahun 1995 CCE merekomendasikan empat hal, yaitu: (1) konten pendidikan harus mengurangi pengajaran pengetahuan atau menghapal bahan, dan isi harus benar-benar dipilih untuk memastikan bahwa anak-anak memiliki pemahaman yang kuat tentang dasar-dasar pendidikan, untuk itu,jumlah jam mengajar harus dipersingkat; (2) fleksibilitas ditekankan dalam kurikulum sebagai upaya mendorong siswa mengembangkan kepribadian khas mereka sendiri untuk menciptakan sekolah yang sesuai karakteristik khas mereka sendiri; (3) upaya menumbuhkan rasa tinggi kemanusiaan pada siswa dan fisik yang kuat, maka kedekatan dengan alam dan pengalman harus ditingkatkan; dan (4) "school periods for integrated learning, sogo gakushu no jikan” harus didirikan dengan tujuan untuk mengenalkan lintas-

${ }^{15}$ Yasuo Saito, Education In Japan, Past And Present, H. 10.

16 Yasusuki Iwata, On "Japanese Style" Teacher Education Reform: Considering Issues Of Quality Development Under An “Open System”, Teacher Education Reform Educational Studies In Japan: International Yearbook No. 9, March, 2015, H. 82-83. Http://Files.Eric.Ed.Gov/ Fulltext/Ej1064145.Pdf 
kurikuler,studi komprehensif seperti pemahaman internasional, pendidikan informasi,perlindungan lingkungan, dan pengalaman di lapangan (alam). ${ }^{17}$

Akhirnya, perubahan kurikulum diadakan lagi di mana pada tanggal 28 Maret 2008, CCE mengumumkan program baru Sekolah Dasar dan Sekolah Menengah yang akan dilaksanakan mulai April 2011. Menurut Penjelasan Kementerian, bahkan dalam kurikulum baru, ide dasar dari "ikiru chikara" akan dipertahankan sebagai prinsip pendidikan. Namun, ada beberapa perubahan dalam kurikulum baru,sebagai berikut:

1. di sekolah dasar (primary school) dan sekolah menengah pertama (lower secondary school), jumlah jam mengajar akan akan meningkat sekitar 10\%;

2. di sekolah dasar, menambah dua jam mengajar dalam seminggu untuk tingkat/kelas 1 dan 2 dan menambah satu jam mengajar dalam seminggu pada kelas 3 sampai 6;

3. di sekolah menengah, ditambah satu jam mengajar dalam seminggu untuk semua tingkat/kelas (7 sampai 9);

4. di sekolah dasar, satu jam diperkenalkan bahasa Inggris pada kelas 5 dan 6;

5. di sekolah dasar, waktu "integrated studies" akan berkurang dari tiga jam menjadi dua jam seminggu;

6. di sekolah menengah pertama, waktu "integrated studies" akan dikurangi dari 2 atau tiga menjadi 2 jam seminggu untuk kelas 1 sampai $4 .^{18}$

\section{Singapura}

Kemerdekaan lepas dari Inggris pada tahun 1959 dan kemudian pemisahan dari malaysia pada tahun 1965, Singapura tidak memiliki aset apa pun selain pelabuhan lautnya. Tidak ada ekonomi riil, tidak ada pertahanan, dan mendidihnya ketegangan negara-negara tetangga. Selain itu, Singapura harus mengimpor sebagian besar makanan, air dan energi. Republik Singapura kelihatan tidak mungkin untuk menjadi negara kelas dunia dalam kekuatan ekonomi dan pendidikan. Resiko negara yang baru merdeka, lahir suatu kerentanan politik dan ekonomi terhadap negara-negara yang lebih besar dan perubahan global - menciptakan rasa akan pentingya pengambilan kebijakan.

Lee Kuan Yew, perdana Menteri Singapura pertama, menetapkan dua tujuan utama pemerintah, yaitu membagun ekonomi modern dan menciptakan rasa nasionalisme (sense of Singaporean national identity). Dia merekrut orang yang terbaik dan tercerdas untuk masuk ke pemerintah awal dan berusaha untuk mempromosikan pertumbuhan ekonomi dan penciptaan lapangan kerja. Pada tahun 1960, penekanannya adalah pada menarik padat karya manufaktur asing untuk menyediakan lapangan kerja bagi tenaga kerja

\footnotetext{
${ }^{17}$ Yasuo Saito, Education In Japan, Past And Present, H. 11.

${ }^{18}$ Yasuo Saito, Education In Japan, Past And Present, H. 12-13.
} 
berketerampilan rendah. Pada 1970-an dan 1980-an, pergeseran ke lebih keterampilanintensif manufaktur menyebabkan penekanan pada bidang teknik. Dari pertengahan tahun 1990-an, Singapura telah berusaha untuk menjadi pemain dalam ekonomi pengetahuan global, mendorong lebih banyak penelitian- dan inovasi-intensif industri dan berusaha untuk menarik para ilmuwan dan perusahaan ilmiah dari seluruh dunia. Hasil kebijakan ekonomi pemerintah telah menakjubkan - pertumbuhan ekonomi yang cepat untuk mencapai tingkat negara maju dan pendapatan per kapita pada tahun 2009 diperkirakan mencapai harga pasar saat ini menjadi sekitar SGP 52000 (USD 39 000). Sehingga saat ini, Sebagai "Singa Asia", Singapura adalah pasar besar, ramah bisnis dan ekonomi yang berorientasi global dalam sebuah bingkai aktif intervensi pemerintah. ${ }^{19}$

Ada sebuah pertanyaan, kenapa Singapura begitu cepat pertumbuhan ekonominya? Hal ini terjadi karena pendidikan Singapura sangat maju dan dianggap melampaui Finlandia yang beberapa tahun belakangan menjadi pemegang rekor pendidikan terbaik dunia. Kebijakan pemerintah untuk membangun sistem pendidikan yang maju didukung semua rakyat Singapura. Ditingkat sekolah, Perdana Menteri Singapura Goh Chok Tong menciptakan visi pendidikan baru pada tahun 1997, yaitu "thinking schools, learning nation” (TSLN). TSLN ini menggambarkan bagaimana bangsa berpikir dan warga pun ikut memiliki komitmen untuk mampu memenuhi tantangan masa depan, dan suatu sistem pendidikan disesuaikan dengan kebutuhan dari abad ke-21. Hal ini terus menjadi lompatan (over-arching) penciptaan transformasi dalam sistem pendidikan, meliputi perubahan dalam semua aspek pendidikan. ${ }^{20}$ Selain itu, Goh Chok Thong menyatakan, "The wealth of a nation lies in its people", kekayaan suatu bangsa terletak pada rakyatnya. Sejak berdirinya republik ini, pendidikan ditempatkan pada posisi atau nilai tinggi sebagai kunci untuk pembangunan ekonomi dan kohesi nasional di negara tanpa sumber daya alam yang jelas. $^{21}$

Penempatan posisi strategis pendidikan untuk mendongkrak pertumbuhan ekonomi, maka pemerintah Singapura memiliki visi yang sangat jelas tentang apa yang dibutuhkan dalam pendidikan. Ini berarti bahwa pelayanan pendidikan didasarkan pada rancangan kebijakan yang akan memenuhi visi pendidikan yang telah ditetapkan. Singapura memiliki sistem terpadu yang unik. Departemen tenaga kerja bekerja dengan berbagai lembaga ekonomi (seperti Dewan Pembangunan Ekonomi) bertanggung jawab untuk mempromosikan kelompok industri tertentu untuk mengkritisi dan mengidentifikasi kebutuhan tenaga kerja dan tuntutan industri (proyek) untuk keterampilan masa depan. Ini

${ }^{19}$ Oedc (The Organisation For Economic Co-Operation And Development), Strong Performers And Succesful Reformers In Education: Lessons From Pisa For The United States, Singapore Rapid Improvment Followed By Strong Performance, H. 160. Https: / /Www.Oecd.Org/Countries/ Singapore/46581101.Pdf

${ }^{20}$ Singapore Ministry Of Education, Building A National Education System For The 21st Century: The Singapore Experience, July 2010. H.. 3. Http://Www.Edu.Gov.On.Ca/Bb4e/Singapore Casestudy2010.Pdf.

${ }^{21}$ Oedc (The Organisation For Economic Co-Operation And Development), H.. 162-165. 
kemudian digunanakan sebagai bahan pelatihan dan pendidikan berkelanjutan atau vokasional. Pemerintah Singapura meyakini percaya bahwa pendekatan perencanaan tenaga kerja akan membantu siswa untuk tumbuh dan bergerak lebih cepat, mengurangi kelebihan pasokan di daerah, dan target dana publik yang lebih efisien untuk pendidikan pascasekolah menengah. Kementerian pendidikan dan lembaga-lembaga pendidikan tinggi dan post-secondary kemudian menggunakan keterampilan proyeksi ini untuk membuat perencanaan pendidikan mereka sendiri, terutama untuk universitas, politeknik dan institut teknik. $^{22}$

Kebijakan pemerintah terkait peningkatan mutu pendidikan diawali dengan mutu pendidikan pendidik (Initial teacher education, ITE). The National Institute of Education (NIE) adalah satu-satunya penanggungjawab penyedia guru di Singapura yang harus memastikan bahwa lulusan ITE berkualitas dan dibekali dengan pengetahuan untuk mengatasi tren baru dan tantangan dalam pendidikian. Oleh karena itu, NIE harus memahami dan melakukan berbagai penelitian untuk mendukung pengetahuan dan informasi "in and for ITE”. ${ }^{23}$ Pembentukan NIE diorientasikan untuk menciptakan guru profesional dalam rangka mengimplementasi kurikulum di sekolah berasaskan setrategi reformasi kurikulum yang telah ditetapkan pemerintah tahun 2005, yaitu "teach less learn more" (TLLM). TTLM is about shifting the focus from "quantity" to "quality" in education. "More quality" in terms of classroom interaction, opportunities for expression, the learning of life-long skills and the building of character through innovative and effective teaching approaches. "Less quantity" in terms of rote-learning, repetitive tests, and following prescribed answers and set formulae. ${ }^{24}$

Sebagai contoh, penelitian yang dilakukan Cohran-Smit dan Zeichner tahun 2005 yang disampaikan oleh Nuttall dkk., bahwa di Australia dan Amerika, praktek guru mengajar lebih banyak dipengaruhi oleh waktu persiapan mereka selama masa pendidikan. Ada kebutuhan yang jelas untuk melihat bagaimana pengetahuan dan praktek guru dibentuk oleh persiapan mereka termasuk setelah mereka menyelesaikan program pendidikan formal. Hal ini cocok dengan hasil penelitian Grossman dkk pada tahun 2000 bahwa "study of teachers learning to teach writing during and after their preservice teacher education programme are needed". Hasil hasil ini dijadikan bahan bagi NIE untuk pengembangan mutu pendidikan ITE. ${ }^{25}$

${ }^{22}$ Oedc (The Organisation For Economic Co-Operation And Development), H. 165

${ }^{23}$ Ee Ling Low, C. Hui, Taylor, P. G., \& Ng, P., Towards Evidence-Based Initial Teacher Education In Singapore: A Review Of Current Literature, Australian Journal Of Teacher Education, Vo. 37, 5, May 2012, H. 66. Http:/ /Ro.Ecu.Edu.Au/Cgi/Viewcontent.Cgi?Article=1727\&Context=Ajte.

${ }^{24}$ Singapore Ministry Of Education, Building A National Education System For The 21 st Century, H. 8.

${ }^{25}$ Singapore Ministry Of Education, Building A National Education System For The 21st Century, H. 69-70. 
Pendidikan dan pelatihan Singapura dari sisi kurikulum di orientasikan pada kemampuan praktis disesuaikan dengan kebijakan ekonomi bangsa berkelanjutan yang terintegrasi baik dengan kebijakan ekonomi dan tenaga kerja. Paradigma ekonomi baru menyapu sistem pendidikan, seperti menanamkan inovasi, kemampuan memecahkan masalah, kreatifitas, dan kewirausahaan di jiwa pemuda Singapura di saat yang sama tetap mempertahankan penekanan yang kuat pada penguasaan isi dan nilai-nilai baik. Contohnya, saat ini Singapura bergerak untuk mengembangkan penelitian dan pembangunan di biomedis, farmasi dan sektor media digital yang didukung oleh perubahan kurikulum sains dan matematika, dengan suatu penekanan yang kuat pada ilmu kehidupan, kemampuan berpikir dan aplikasi ilmu pengetahuan, matematika dan pengetahuan teknologi untuk dunia yang sesungguhnya (technological knowledge to the real world). ${ }^{26}$

Kurikulum sekolah terus ditinjau dan direvisi, setiap kali diperlukan, untuk memastikan kesesuaian dalam konteks keseluruhan pembangunan ekonomi dan sosial Singapura. Penekanan kurikulum ditekankan pada pada melek huruf, berhitung, bilingualisme, sains dan pendidikan matematika, seni, serta pendidikan moral. Sekolah didorong untuk menjadi inovatif, mengambil peran yang lebih besar dari program mereka dan sumber daya dan lebih bertanggung jawab kepada semua pemangku kepentingan. Ini adalah keberangkatan yang signifikan dari pendekatan "top-down” yang diambil oleh NIE selama beberapa dekade. Pendidik Afrika juga harus mengakui bahwa guru dan prinsipprinsip adalah kunci untuk kesuksesan transformasi lembaga pendidikan pemerintah dan pedagogi. They are the ones who will nurture and train the workforce of tomorrow. They must be justifiably rewarded. ${ }^{27}$

\section{Pembahasan}

Mencermati realitas pendidikan di negara Australia, Jepang, dan Singapura yang terus mengalami reformasi dari waktu ke waktu, maka transformasi pendidikan nampak begitu penting bagi kemajuan suatu negara. Transformasi pendidikan harus dimulai dari sesuatu yang vital dalam setiap individu. Hal vital ini biasa disebut dengan ideologi yang akan melahirkan suatu "isme" yang bisa disebut sebagai "transformisme". Dalam konteks pengembangan mutu pendidikan di Indonesia, paling tidak ada tiga sasaran utama yang

${ }^{26}$ Goh Cor Boon And S. Gopinathan, The Development Of Education In Singapore Since 1965: Background Paper Prepared For The Asia Education Study Tour For African Policy Makers, June 18 - 30, 2006, National Institute Of Education, Nanyang Technological University, $\quad$ Singapore, $\quad$ H. 50-51. Http://Siteresources. Worldbank. Org/Education/Resources/278200-1121703274255/1439264$1153425508901 /$ Development Edu Singapore Draft.Pdf.

${ }^{27}$ Goh Cor Boon And S. Gopinathan, The Development Of Education, H. 52. 
seharusnya menjadi perhatian khusus dalam mendesain sistem pendidikan nasional, yaitu policy, market and value.

\section{Policy (Kebijakan)}

Transformasi yang terjadi di tiga negara di atas, dari aspek kebijakan, setidaknya ada beberapa kecenderungan, yaitu: pertama, desentralisation. Pendidikan yang baik adalah pendidikan yang secara manajerial diatur oleh lingkungan yang terdekat dengan lembaga pendidikan. Kebijakan akan segera dapat dipahami dan direalisasikan secara kontinu sesuai perkembangan dan kebutuhan yang ditetapkan secara umum oleh pusat. "Do locally think globally",

Kedua, focus on quality. Ungkapan, "Teacher quality was again affirmed as a key determinant of quality education", menjadi dasar filosofis dalam penyediaan tenaga pengajar. Kebijakan penyediaan guru oleh pemerintah bekerja sama dengan universitas dijadikan bentuk reformasi dalam penyediaan tenaga profesional untuk mengawal kurikulum yang telah diprogramkan. Penyiapan tenaga guru diawal program dipilih untuk efektifitas dan efisiensi implementasi kebijakan kurikulum. Kualitas ini, misalnya menjadi satu tujuan utama Jepang dalam frasa "Ikiru Chikara" yang memerlukan jiwa "yutori" pada sekolah, keluarga, dan masyarakat.

Ketiga, fokus on proyection. Perlakuan terhadap institusi pendidikan, guru, murid diproyeksikan bukan untuk saat ini, tetapi untuk menghadapi situasi dan kondisi yang akan dihadapi negara di masa mendatang. Semua upaya didasarkan pada riset untuk menangkap orientasi perkembangan global. Pendirian lembaga-lembaga yang fokus untuk pengembangan SDM yang responsif terhadap perkembangan ilmu dan teknologi, seperti Institute for Professional Learning (IPL), NCER, dan NIE.

\section{Market (Pasar)}

Negara atau khususnya orang tua murid sebagai konsumen tentunya mengaharapkan output dari lembaga pendidikan diterima di dunia kerja baik di dalam negeri maupun di luar negeri. Pendidikan dalam kontek pasar ini sangat erat kaitannya dengan ekonomi. Pendidikan mengikuti perkembangan ekonomi dan demikian juga perkembangan ekonomi ditunjang oleh fleksibiltas pendidikan dalam merancang kurikulum yang marketable. Perdidikan berbasis pasar ini dapat dilihat dari beberapa kebijakan di negara Austalia, Jepang dan Singapura.

Sebagai contoh, penerapan NPM di Australia berupaya merubah dari administrasi publik yang kaku, hierarkis, dan birokratis menuju bentuk manajemen publik yang fleksibel dan berbasis pasar. Di Jepang untuk menghadapi masalah yang sulit dihadapi pada era global, mereka berupaya mendirikan "sogo gakushu no jikan" dengan tujuan untuk mengenalkan lintas-kurikuler,studi komprehensif seperti pemahaman internasional, 
pendidikan informasi, perlindungan lingkungan, dan pengalaman di lapangan (alam). Pendidikan berorientasi pasar ini terdapat di Singapura, kurikulum pendidikan diorientasikan pada kemampuan praktis disesuaikan dengan kebijakan ekonomi bangsa berkelanjutan yang terintegrasi baik dengan kebijakan ekonomi dan tenaga kerja. Paradigma ekonomi baru menyapu sistem pendidikan, seperti menanamkan inovasi, kemampuan memecahkan masalah, kreatifitas, dan kewirausahaan di jiwa pemuda Singapura. Sehingga kurikulum sekolah terus ditinjau dan direvisi, setiap kali diperlukan, untuk memastikan kesesuaian dalam konteks keseluruhan pembangunan ekonomi dan sosial Singapura. Sebagai bukti keberhasilan Singapura menurut Richard O. Welsh pertumbuhan ekonomi Singapura melesat dibandingkan Jamaika di mana tahun 1960, per capita GDP Singapura berada di bawah Jamaika $(\$ 4,383$ vs $\$ 6,417)$ dan pada tahun 2010 , per capita GDP Singapura berada pada $\$ 55,862$ sedangkan Jamaika stagnan di posisi $\$ 8,539$. $^{28}$

Pada kenyataannya, sangat jelas bahwa kurikulum dilihat sebagai suatu hakekat dalam bentuk abstrak dari dunia kerja. Peningkatan mutu pendidikan terus diupayakan dalam menjangkau standar pendidikan yang ideal dan relevansinya dengan kebutuhan dunia kerja. Kebutuhan dunia kerja dapat dipilah menjadi dua sisi tenaga kerja, yaitu tenaga manajerial dan tenaga teknis operasional. Untuk memenuhi kebutuhan pasar tersebut, di tiga negara maju tersebut, lembaga pendidikan (khususnya PT) terbagi menjadi dua, yaitu bercorak akademis dan bercorak vokasional.

Value (nilai)

Penciptaan atau perancangan pendidikan yang berorientasi pada nilai-nilai kemanusiaan menjadi perhatian utama negara-negara maju. Nilai yang berintikan moral dapat dilihat dari pembangunan manusia baik di Australia, Jepang maupun Singapura. Moral inilah yang kemudian menjadi pondasi maha kuat dalam setiap program-program pengembangan mtu pendidikan di negara tersebut.

Australia mengawali peningkatan mutu pendidikan dengan menyusun Curriculum Framework, yang di dalamnya terdapat 5 karakter nilai yang akan dibangun dalam kurikulum pendidikan. Dari 5 karakter nilai itu, terdapat 4 nilai terkait dengan moral, yaitu penerimaan dan penghormatan diri sendiri, rasa hormat dan peduli pada orang lain dan hak-hak mereka, tanggung jawab sosial dan kemasyarakatan, tanggung jawab terhadap lingkungan.

28 Richard O. Welsh (University Of Southern California), Overcoming Smallnes Through Education Development: A Comparative Analysis Of Jamaica And Singapore, Article (C) 2012 Current Issues In Comparative Education, Teachers College, Columbia University, All Rights Reserved Current Issues In Comparative Education 15 (1). H. 117. Http://Www.Tc.Columbia.Edu/ Cice/Pdf/26009_15_01_Welsh.Pdf. 
Masalah moral pun menjadi sasaran penting pendidikan di Jepang. Fakta sejarah menunjukkan bahwa peradaban Jepang dibangun di atas nilai-nilai tradisi yang kuat diturunkan dan diwariskan dari generasi ke generasi. Mereka pernah berada pada puncak "pendewaan" akademik dan lupa akan pentingnya nilai atau moral dalam masyarakat sehingga memunculkan istilah "examination hell syndrom" sehingga generasi bangsa perlu dipersiapkan dengan kualitas dan kemampuan, salah satunya adalah tinggi rasa kemanusiaan, penekanan kemampuan untuk mengendalikan diri, kesediaan untuk bekerja sama dengan orang lain, dan hati yang memungkinkan mereka untuk peduli kepada orang lain dan menjadi sensitif terhadap sesuatu yang berharga dan mulia.

Penekanan masalah nilai atau moral di Singapura dapat tercermin dari upaya menumbuh jiwa inovasi, problem solving, kreatif, dan kewirausaan di jiwa pemuda Singapura berbanding lurus dengan upaya mempertahankan penekanan yang kuat pada penguasaan isi dan nilai-nilai baik. Hal ini dilakukan dengan memasukkan pendidikan moral dalam kurikulum di setiap jenjang pendidikan dan sekolah memiliki rasa lebih bertanggung jawab kepada semua pemangku kepentingan.

\section{PENUTUP}

Pengembangan mutu pendidikan di negara maju, seperti di Australia, Jepang, dan Singapura diawali dari prinsip negara yang diikuti seluruh elemen bangsa tentang apa yang harus dilakukan bersama menuju negara berpendidikan. Kemudian, negara dituntut membuat kebijakan yang dinamis sesuai perkembangan global atau internasional, seperti halnya dalam kerangka pendidikan. Sistem pendidikan didasarkan pada filosofi bahwa pendidikan adalah urusan bersama antara pemerintah, pelaku industri, dan masyarakat secara umum. Maka dari itu, sinergi ketiga komponen utama ini mutlak diperlukan dalam membangun mutu pendidikan yang berstandar global.

Pendidikan di negara maju dibangun oleh budaya tunggal untuk mewujudkan "learning society” yang digerakkan oleh kebijakan pemerintah, pasar kerja, dan nilai moral dalam kerangka profesionalitas para pelaksana pendidikan di mulai dari pejabat struktural sampai pejabat fungsional (guru). Oleh karena itu, dari tingkat kindergarten sampai tingkat university, kurikulum diupayakan menjalankan program umum dari pusat dengan menjalankan program pendidikan dan pelatihan yang akan digunakan untuk memenuhi kebutuhan tenaga kerja yang memiliki skill dan nilai moral. Dengan skill dan nilai moral yang dibangun oleh pendidikan yang mandiri dan bertangungjawab akan melahirkan generasi bangsa yang memiliki inovasi dan kreatifitas untuk menciptakan tatanan global yang maju, modern namun tetap menjunjung tinggi nilai-nilai yang positif bagi kelangsungan hidup manusia. 
Kurikulum sebagai wujud upaya menangkap kebutuhan global terus diupayakan diperbaiki dan dikembangkan berdasar pada pembangunan ekonomi dan sosial berwawasan global. Pendidikan harus responsif terhadap kebutuhan industri yang terus berkembang seiring perkembangan teknologi informasi dan komunikasi. Akan tetapi, secara sosial pendidikan perlu terus menekankan pembangunan manusia sebagai individu yang memiliki tangungjawab etis untuk mengarahkan gerak positif kehidupan. Akhirnya akan tercapai visi dasar pendidikan menurut Unesco abad XXI, yaitu learning to know, learning to do, learning to be and learning to life togather.

\section{DAFTAR PUSTAKA}

Boon, Goh Chor and S. Gopinathan. 2006. The Development of Education in Singapore since 1965: Background paper prepared for the Asia Education Study Tour for African Policy Makers. National Institute of Education, Nanyang Technological University, Singapore.

Esha, Muhammad In'am. 2009. Institutional Transformation: Reformasi dan Modernisasi Pendidikan Tinggi Islam, Malang: UIN-Malang Press.

Iwata, Yasusuki. 2015. On "Japanese Style" Teacher Education Reform: Considering Issues of Quality Development under an "Open System", Teacher Education Reform Educational Studies. Japan: International Yearbook.

Lie, Tram, Periode I, World History II: Japan Revolusion Essay.

Low, Ee Ling, C. Hui, Taylor, P. G., \& Ng, P., 2012. Towards Evidence-based Initial Teacher Education in Singapore: A Review of Current Literature. Australian Journal of Teacher Education, Vol. 37, 5.

Mawardi. 2014. Standar Kualifikasi dan Kompetensi Guru Profesional Di Indonesia dan Australia Barat. E-Journal Scholaria, Vol. 4, No. 2.

OEDC (the Organisation for Economic Co-operation and Development), Strong Performers and Succesful reformers in Education: Lessons from Pisa for The United States, Singapore Rapid Improvment Followed by Strong performance.

Richard O. Welsh. 2012. Overcoming Smallnes Through Education Development: A Comparative Analysis of Jamaica and Singapore, article (C) 2012 Current Issues in Comparative Education, Teachers College. Columbia University, All Rights Reserved Current Issues in comparative Education 15 (1).

Saifullah. 2014. Konsep Pendidikan Jerman dan Australia (Kajian Komparatif dan Aplikatif terhadap Mutu Pendidikan Indonesia). JIP-International Multidisciplinary Journal, Vol. II, No. 02. 
Saito, Yasuo. Education in Japan, Past and Present. Japan Tokyo: National Institute for Educational Policy Research of Japan, 3-2-2 Kasumigaseki, Chiyoda-ku, Tokyo, 1008951.

Singapore Ministry of Education. 2010. Building a National Education System for the 21st century: The Singapore Experience.

The Goverment of Western Australia. 2014. Departement of Education and Trainning, Competency Framework For Teachers. 151 Royal Street East Perth WA 6004.

http://www.belajarluarnegeri.com/belajar-di-australia/

http://www.rri.co.id/samarinda/post/berita/246610/luar_negeri/mahasiswa_indonesia_yan g_kuliah_di_australia_mencapai_640_ribu_orang.html. 